This item was submitted to Loughborough's Research Repository by the author.

Items in Figshare are protected by copyright, with all rights reserved, unless otherwise indicated.

\title{
Institutional quality and economic development in sub-Saharan Africa: Can management effort and bribes compensate for low-quality institutions?
}

\section{PLEASE CITE THE PUBLISHED VERSION}

https://doi.org/10.1080/00213624.2018.1469920

\section{PUBLISHER}

CJournal of Economic Issues / Association for Evolutionary Economics. Published by Taylor \& Francis (Routledge)

\section{VERSION}

AM (Accepted Manuscript)

\section{PUBLISHER STATEMENT}

This is an Accepted Manuscript of an article published by Taylor \& Francis in Journal of Economic Issues on 11th June 2018, available online: https://doi.org/10.1080/00213624.2018.1469920

\section{LICENCE}

CC BY-NC-ND 4.0

\section{REPOSITORY RECORD}

Daniel, Gori Olusina, Kun Fu, and Wilfred Dolfsma. 2019. "Institutional Quality and Economic Development in Sub-saharan Africa: Can Management Effort and Bribes Compensate for Low-quality Institutions?”. figshare. https://hdl.handle.net/2134/32262. 


\section{Institutional quality and economic development in sub-Saharan Africa: Can management effort and bribes compensate for low-quality institutions?}

Gori Olusina Daniel, Kun Fu, Wilfred Dolfsma (*)

Loughborough University, London; Institute for Innovation \& Entrepreneurship;

3 Lesney Avenue, Broadcast center, Here East, QEOP; London E15 2GZ; UK

(*) Corresponding author; w.a.dolfsma@lboro.ac.uk

\section{Abstract}

The industrial development in sub-Saharan Africa is perhaps more affected by the quality of institutions than that of other regions. We investigate what alternatives managers have to secure what their firms need to function in case the institutional furniture they are confronted with is of low quality. We find that in high quality institutional environments management spending effort dealing with authorities and navigating regulations negates the effect of the institutional environment. Managers do not need to spend these efforts. Perhaps surprisingly, we find that the positive effect of high-quality institutional environments on firm performance is enhanced by making informal payments.

\section{INTRODUCTION: Institutions and Firms}

Harry Trebing (1987) convincingly argued against a then mainstream consensus in economics that industry should face as little regulation as possible. The implicit assumption driving this view was that government failure was more likely or more detrimental than the market failures that were recognized. Trebing and others, prominent among these institutional economists, have since been able to demonstrate that the proper functioning of markets is dependent on appropriate institutions being in place as markets are necessarily embedded in society (see Dolfsma, 2013). 
Mainstream economists and policymakers have, after North (1990), also embraced the idea that institutions affect the economy and firm performance. The World Bank (1998) and others, have since followed suit. A view has taken hold that if and when developing countries put in place the formal institutions that characterize western economies, private firms operating in their economies would benefit (Khanna and Palepu, 2000; Lee and Kim, 2009; Mair and Marti, 2009; Sutter et al., 2013). Without such institutions, an 'institutional void' is believed to exist that hampers firms' performance (Mair et al., 2012). Others have indicated, in contrast, that in such circumstances of absent formal institutions that regulate the economic domain, institutions still affect firms. These can be informal institutions, or formal institutions from a different, adjacent practice or domain (see Olthaar et al., 2017).

In this brief paper we address another potentially problematic untested view underlying the institutional void thesis: the idea that an inappropriate or unsatisfactory institutional 'furniture' (Veblen 1961, p.236) forces entrepreneurs and managers of firms (we will also refer to this as Top Management Team - TMT) to seek alternative routes to obtain what they need for their firm to function.

In this view, the preferred route is one where entrepreneurs and managers rely on clear, predictable and enforced formal rules that treat all equally; and equally efficiently. Consequently, in high-quality institutional environments, responses from public authorities and service providers become predictable in their nature and speed of delivery (World Bank 1998, p.15). Public authorities and service providers deliver a range of key services to firms such as licences, permits, access to electricity, tax administration, legal underpinning of contracts between parties, and certainty of property rights. When public institutions are of high quality, firms can focus their efforts and resources on production and other more directly value creating activities.

Without high quality institutions, again, in this view, entrepreneurs and managers must either spend a lot of effort navigating the inefficient regulatory system, or resort to other measures - such as informal payments (i.e. gifts or bribes') to create an obligation (Darr, 2003; Dolfsma et al. 2008) - to try to ensure that the interests of individuals working in public authorities and service providers will be aligned with those of private citizens and TMT members alike.

Low-quality institutions can therefore increase the transaction costs of dealing with public authorities as they give individuals at all levels in these government agencies the opportunity to have their own interests prevail over those of the agency or of society as a whole. In such circumstances of government failure (cf. Dolfsma, 2013), extra efforts may be required by non-principal individuals and TMT members in visiting authorities repeatedly, by monitoring procedures, or by obtaining the resources firms require from rogue agents. Under these conditions, informal payments as described, and TMT efforts, are thus perceived as substitutes for the quality of the institutional furniture; and can be thought to compensate for the strength or quality of a country's institutional furniture. 
Figure 1 illustrates the conceptual model that characterises informal payments and TMT efforts as substitutes for the quality of the institutional furniture in a country.

$<$ Figure 1>

We empirically test this view directly in this short paper. Focusing on sub-Saharan Africa is appropriate as institutional quality varies substantially, following the differing pace and success of reforms to deepen democratic values and institutions, and adopt market liberating policies since the 1990s (UNCTAD \& UNIDO, 2011); and that TMT efforts dealing with an inefficient regulatory system, as well as the prevalence of informal payments, are believed to be rife.

\section{METHOD}

Data and Sample. We use the World Bank Enterprise Surveys (WBES) of firm-level data, which contains information about private firms from key manufacturing and service sectors across 139 countries in the world. The Enterprise Surveys adopt standardized survey instruments and a uniform sampling frame to produce a representative sample and harmonised data that are comparable across a wide range of economies, which enables understanding of how and which factors and institutions in the business environment affect firm performance over time and across countries (World Bank, 2007). We draw on other sources of data to compile the country-level variables such as the Economic Freedom Index provided by the Fraser Institute, the data on country's overall socioeconomic conditions from the World Bank and the IMF. We draw the sample from a population of firms surveyed from 35 African countries over a 10-year period of time between 2006 and 2015. A total of 17,757 observations are included in the sample.

Dependent variable. Firm performance is the dependent variable and is measured by a fiscal year's total sales of a firm. We convert the local currency into the internal dollar and factor in the purchasing power parity to ensure the comparability across countries over time.

Independent variables. Institutional Effectiveness is concerned with how well institutions relate with each other, and are fit for purpose from the perspective of the wider society (Rodriguez-Pose, 2013). We measure this by the overall degree of economic freedom index provided by the Fraser Institute, which draws on a composite measure of 42 distinct variables across five major areas a) Size of Government; b) Legal system and security of property rights $\mathrm{c}$ ) Sound money d) Freedom to trade internationally; and e) Regulation. Top management effort is the percent of senior management's time spent in dealing with regulations. We measure it by taking the difference between a firm's TMT effort and the sector-level average value of TMT effort within the country in which the firm is located. Informal payment is often seen that gifts or informal payments are paid to public officials to "get things done" with regard to customs, taxes, licenses, regulations, services etc. This is measured by the percent of a firm's total annual sales paid as informal payment. 
Control variables. We control for a set of firm-level and country-level variables, which are associated with firms' performance and measured as follows. Age of a firm (see Johanson \& Vahlne, 1990) is measured by the difference between the year of observation and the year in which the firm was formally registered. Size of a firm (see Schumpeter, 1947) is measured by the number of employees of the firm, and coded as a categorical variable taking the value ' 1 ' for small size firms with less than 20 employees, ' 2 ' for medium size firms with less than 100 employees, and ' 3 ' for large size firms with no less than 100 employees. The industrial sector in which a firm's primary business lies, which is measured by a categorical variable taking the value ' 1 ' for manufacturing industry, ' 2 ' for service industry, and ' 3 ' for other industries. Ownership of a firm (see McGahan \& Victer, 2009) is measured by the percent of the firm owned by private foreign individuals, companies or organizations. It is measured by a dummy variable and we assign the value " 1 " for foreign firms with more than $50 \%$ of the firm is owned by foreigners, and " 0 " for domestic firms. Manager's experience (Ayyagari et al., 2011) is measured by the number of years a firm's top manager has been working in the sector. Because a country's wealth has been shown to influence firms' performance, we control for the country's GDP per capita (USD) adjusted for purchasing power parity (PPP). We control for population size of country as it captures the market size within the country. The year effect is controlled for as well.

Data Analyses. The WBES dataset is hierarchical in structure, which means that the firm-level observations are nested within the country-level observations. With this data structure, firm-level data are likely to be correlated within countries. Traditional multiple regressions such as the ordinary least square regressions with a pooled data could result in biased estimations due to ignoring the nested data structure, thus violating the assumption of data independence (Hofmann et al., 2000). We therefore apply multi-level modelling techniques to analyse the data while accounting for the hierarchical structure of the dataset. We specify a two-level model with random intercept to evaluate firms' performance by factoring in both the impact of institutional conditions at the country-level and the influence of informal payment and top management effort at the firm-level at the same time. The models are specified below.

Level-1 equation:

$$
Y_{i j}=\beta_{0 j+} \beta_{1 j} X_{i j}+e_{i j}
$$

Level-2 equations:

$$
\begin{gathered}
\beta_{0 j}=\gamma_{00}+\gamma_{01} W_{j}+u_{0 j} \\
\beta_{1 j}=\gamma_{10}+u_{1 j}
\end{gathered}
$$

The level-1 equation predicts the direct effects (i.e. betas) of level-1 predictors on level-1 outcomes, where $Y_{i j}$ is the dependent variable for an individual observation at level 1 (subscript i refers to a firm, subscript j refers to the country that the firm belongs to). $X_{i j}$ is the firm-level (level-1) predictor. $\beta_{0 j}$ is the intercept of the dependent variable in country $\mathrm{j}$ 
(level-2). $\beta_{1 j}$ is the slope for the relationship in country $\mathrm{j}$ between the firm -level predictor and the dependent variable. $e_{i j}$ is the firm -level residual. The level-2 equations predict the effects (i.e., gammas) of level-2 predictors on level-1 betas as well as on the level-1 intercept, where $\gamma_{00}$ is the overall intercept, which is the mean of the intercepts across countries. $W_{j}$ is the country-level predictor. $\gamma_{01}$ is the slope or main effect of country-level predictor. $\gamma_{10}$ is the slope or main effect of individual-level predictor. $u_{0 j}$ and $u_{1 j}$ are country-level residuals. Variance inflation factors (VIFs) of all variables in the model are between 1.04 and 2.9, indicating our analysis is unlikely to be influenced by multicollinearity between variables. The multilevel equation specified in this study is:

$$
\begin{aligned}
Y_{i j}=\gamma_{00+} \gamma_{01} \text { InstitutionEffectiveness }_{j}+\gamma_{02} \text { GDPperCap }_{j}+\gamma_{03} \text { Population }_{j} \\
\\
+\gamma_{10} \text { TopManagemnetEffort }_{i j}+\gamma_{20} \text { Size }_{i j}+\gamma_{30} \text { Age }_{i j}+\gamma_{40} \text { Ownership }_{i j} \\
\\
+\gamma_{50} \text { ManagerExperience }_{i j}+\gamma_{60} \text { Sector }_{i j}+\gamma_{70} \text { Year }_{i j}+u_{0 j}+e_{i j}
\end{aligned}
$$

\section{RESULTS}

Table 1 reports the descriptive statistics and correlations of all variables for the analysis.

Table 2 shows the regressions results, in which Model 1 is the baseline model including only control variables; Model 2 is the main effect model containing the key explanatory variables; Model 3 is the full model with interaction terms added to the model. The likelihood ratio tests show that adding institutional effectiveness, top management effort and informal payment as independent variables together in Model 2 and interaction terms in Model 3 both result in a statistically significant improvement in model fit ( $L R \operatorname{chi}^{2}(3)$ $=237.5, p<0.001$ and $L R$ chi $^{2}(2)=28.21, p<0.001$ respectively).

\section{Insert Tables 1 and 2 about here}

Results in Table 2 show that our expectation that top management effort as well as informal payments can be used as substitutes for effective institutions only holds true for the former. Indeed, less top management effort is required to navigate regulations in high-quality institutional environments, typically characterised by clear, predictable, and properly enforced rules and regulations (World Bank, 1998). TMT efforts dealing with authorities and regulations also has a significant direct impact on firm performance. What is perhaps surprising, however, is that informal payments are not a substitute for low-quality institutional environments. The positive effect of high quality institutions on firm performance is enhanced by a firm making informal payments. Informal payments do not have a direct effect themselves on firm performance, as expected. We graphically illustrate 
the interaction effects of top management effort and informal payments each matched against the overall institutional effectiveness of countries in Figures 2 and 3 respectively.

Insert Figures 2 and 3 about here

\section{DISCUSSION: BRIBES AND INSTITUTIONAL QUALITY}

The finding that informal payments enhance institutional quality's positive impact on firm performance is an unexpected one. We can offer a number of possible explanations.

First, it might be that for a study that focuses on other regions, perhaps economically more developed, might return different results. Sub-Saharan Africa countries that have relatively high institutional quality might still not have high enough quality of institutions that are free from political interference, treat all equally and, equally efficiently. Also, the practice of gift giving might be more culturally expected and accepted in sub-Saharan Africa. One should be aware, however, that anthropological studies have found the practice of gift giving rife across a range of countries. In developed countries there might be more regulation restricting the practice, and certainly the size of gifts, but gift giving happens nonetheless there as well (Dolfsma et al. 2009; Offer 1997; Smart 1983).

We therefore believe that a second explanation for our remarkable finding is more plausible. Mauss (1954) has argued that there are three essential aspects of gift giving: giving, receiving and reciprocating. Reciprocation should not occur immediately, and what is reciprocated should not be predetermined in value. Gift giving thus creates and sustains relationships between concrete individuals. In a society that is characterized by low institutional quality, much uncertainty exists and the circumstances for relations to be stable may be absent. When giving a gift, the giver may not be sure that the givee is there to return a favour at some later stage. A givee will perhaps also be more inclined to treat an informal payment as a ransom payment rather than a gift to be reciprocated.

\section{CONCLUSION}

Institutional economists will not be surprised that high quality institutions in a society will make firms perform better. We find, as expected, that the efforts that a firm's top management spends on dealing with regulation are a substitute for high quality institutions. What is surprising to scholars who implicitly would claim that formal institutions are of paramount importance for the economy, is that informal payments actually enhance the positive contribution of high-quality institutions to firm performance. We submit that this is 
further support for the view that economists and policy makers need to adopt a more comprehensive understanding of how (and which) formal as well as informal institutions impact the economy in general, and firm performance in particular.

\section{REFERENCES}

Ayyagari, M., Demirgüç-Kunt, A., \& Maksimovic, V. (2011). Firm innovation in emerging markets: the role of finance, governance, and competition. Journal of Financial and Quantitative Analysis, 46(06), 1545-1580.

Bailey (2013), 'Entrepreneurs' Responses to Semi-Formal Illegitimate Institutional Arrangements', Journal of Business Venturing, 28(6): 743-758.

Burki, S. J. and Perry, G. E. (1998) Beyond the Washington Consensus: institutions matter. World Bank Latin American and Caribbean Studies, Viewpoints. ISBN: 0-8213-4282-7

Darr, A. (2003) Gifting Practices and Inter-Organisational Relations: Constructing Obligations Networks in Electronics Sector. Sociological Forum 18(1), p31-51.

Dolfsma, W. (2013) Government Failure. Cheltenham: Edward Elgar.

Dolfsma, W., R. Van der Eijk \& A. Jolink (2008). On a Source of Social Capital: Gift Exchange. Journal of Business Ethics 89: 315-329.

Hofmann, D. A., Griffin, M. A., and Gavin, M. B. (2000), 'The application of hierarchical linear modeling to organizational research'. In K. J. Klein, \& S. W. J. Kozlowski (Eds.), Multilevel theory, research, and methods in organizations. pp. 467-511. San Francisco, CA: Jossey-Bass.

Khanna, T. and K. Palepu (2000), 'The Future of Business Groups in Emerging Markets: LongRun Evidence from Chile', Academy of Management Journal, 43(3): 268- 285.

Johanson, J., \& Vahlne, J.-E. (1990). The mechanism of internationalisation. International Marketing Review, 7(4), 11-24.

Lee, K. and B.-Y. Kim (2009), 'Both Institutions and Policies Matter but Differently for Different Income Groups of Countries: Determinants of Long-Run Economic Growth Revisited', World Development, 37(3), 533-549.

Mair, J., Marti, I., and Ventresc M. J. (2012), 'Building Inclusive Markets in Rural Bangladesh: How Intermediaries Work Institutional Voids', Academy of Management Journal, 55(4): 819-850.

Mauss, M. (1954 [2000]). The Gift: Forms and Functions of Exchange in Archaic Societies. New York: Norton.

McGahan, A. M., \& Victer, R. (2009). How much does home country matter to corporate profitability? Journal of International Business Studies, 41(1), 142-165.

North, D. C. (1990), Institutions, Institutional Change, and Economic Performance, Cambridge, UK: Cambridge University Press.

Offer, A. (1997). 'Between the Gift and the Market: The Economy of Regard', Economic 
History Review 50(3), 450-476.

Olthaar, M., Dolfsma, W., Lutz, C. and Noseleit, F. (2017), 'Markets and institutional swamps: tensions confronting entrepreneurs in developing countries' Journal of Institutional Economics, 13(2), 243-269.

Rodriguez-Pose, A. (2013). Do institutions matter for regional development? Regional Studies, 47, 1034-1047.

Rose-Ackerman, S.: 1998, 'Bribes and Gifts', in A. Ben-ner and L. Putterman (eds.), Economics, Values and Organization (Cambridge UP, Cambridge).

Schumpeter, J. (1947). The creative response in economic history. Journal of Economic History, 7(2), 149-159.

Smart, A. (1993). 'Gifts, Bribes, and Guanxi: A Reconsideration of Bourdieu's Social Capital', Cultural Anthropology 8(3), 388-408.

Trebing, Harry M. (1987) "Regulation of Industry: An Institutionalist Approach" Journal of Economic Issues 21(4): 1707- .

UNIDO and UNCTAD (2011) "Economic Development in Africa Report: Fostering industrial developemtn in Africa in the new global environment". Special Issue UNCTAD/ALDC/Africa/2011. [available online http://unctad.org/en/docs/aldcafrica2011_en.pdf]

Veblen, Thorstein B. "The Limitations of Marginal Utility." In: The Place of Science in Modern Civilization, Thorstein Veblen, pp. 231-51. New York: Russell and Russell, 1961.

World Bank's Enterprise Survey: How to implement the survey (2007), World Bank Group [available at www.enterprisesurveys.org.]

Figure 1: Conceptual model

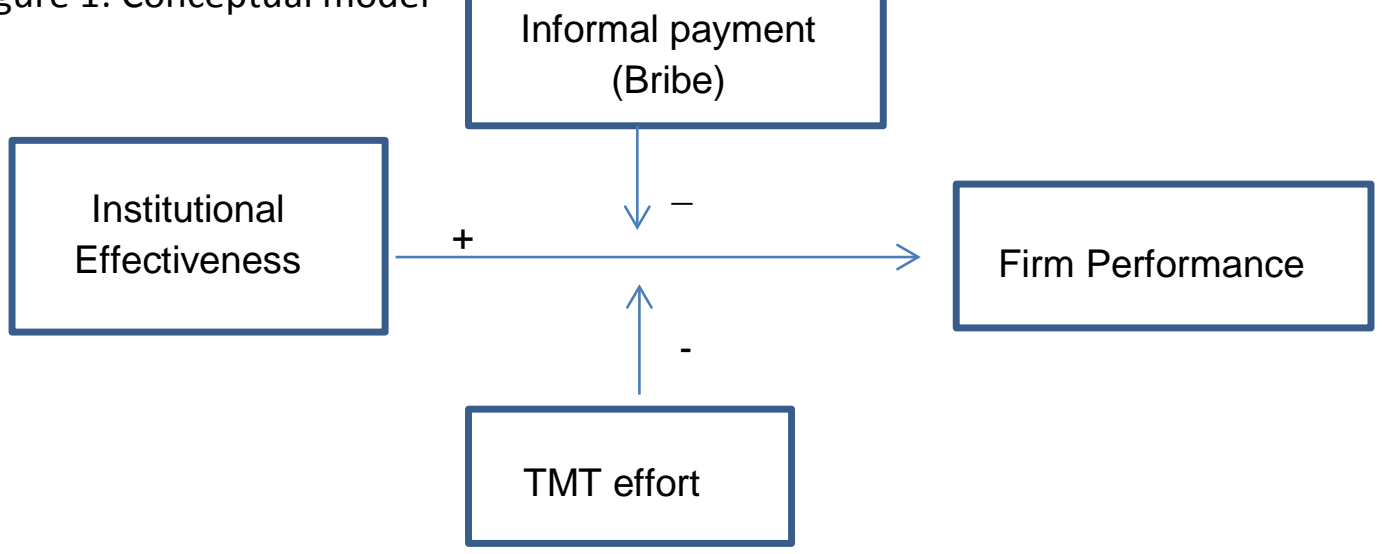


Table 2 Estimation Results Using Multi-level Linear Regression Models

\begin{tabular}{|c|c|c|c|}
\hline & Model 1 & Model 2 & Model 3 \\
\hline \multirow[t]{2}{*}{ Institutional Effectiveness } & & $0.808 * * *$ & $0.805^{* * *}$ \\
\hline & & $(0.054)$ & $(0.054)$ \\
\hline \multirow[t]{2}{*}{ Top Management Effort } & & $0.043^{* * *}$ & $0.039 * * *$ \\
\hline & & $(0.005)$ & $(0.005)$ \\
\hline \multirow[t]{2}{*}{ Informal Payment } & & 0.001 & 0.002 \\
\hline & & $(0.005)$ & $(0.005)$ \\
\hline \multirow[t]{2}{*}{ Top Management Effort X Institutional Effectiveness } & & & $-0.024 * * *$ \\
\hline & & & $(0.006)$ \\
\hline \multirow[t]{2}{*}{ Informal Payment X Institutional Effectiveness } & & & $0.021 * * *$ \\
\hline & & & $(0.006)$ \\
\hline \multirow[t]{2}{*}{ Size (medium) } & $0.499 * * *$ & $0.498 * * *$ & $0.497 * * *$ \\
\hline & $(0.013)$ & $(0.012)$ & $(0.012)$ \\
\hline \multirow[t]{2}{*}{ Size (small) } & $1.190^{* * *}$ & $1.180^{* * *}$ & $1.181 * * *$ \\
\hline & $(0.019)$ & $(0.019)$ & $(0.019)$ \\
\hline \multirow[t]{2}{*}{ Age } & $0.082^{* * *}$ & $0.081^{* * *}$ & $0.081 * * *$ \\
\hline & $(0.007)$ & $(0.007)$ & $(0.007)$ \\
\hline \multirow[t]{2}{*}{ Ownership } & $0.261^{* * *}$ & $0.263^{* * *}$ & $0.262^{* * *}$ \\
\hline & $(0.018)$ & $(0.018)$ & $(0.018)$ \\
\hline \multirow[t]{2}{*}{ Management Experience } & 0.004 & 0.005 & 0.006 \\
\hline & $(0.006)$ & $(0.006)$ & $(0.006)$ \\
\hline \multirow[t]{2}{*}{ Sector (service) } & $0.025^{*}$ & $0.019+$ & $0.020+$ \\
\hline & $(0.011)$ & $(0.011)$ & $(0.011)$ \\
\hline \multirow{2}{*}{ Sector (other) } & -0.026 & -0.016 & -0.015 \\
\hline & $(0.027)$ & $(0.027)$ & $(0.027)$ \\
\hline \multirow[t]{2}{*}{ GDP per cap PPP (USD) } & $-2.418 * * *$ & $-1.743 * * *$ & $-1.755 * * *$ \\
\hline & $(0.132)$ & $(0.128)$ & $(0.128)$ \\
\hline \multirow[t]{2}{*}{ Population (million) } & $5.472 * * *$ & $0.898 * *$ & $0.807^{*}$ \\
\hline & $(0.544)$ & $(0.332)$ & $(0.328)$ \\
\hline \multirow[t]{2}{*}{ Year 2007} & $0.321 * * *$ & $0.159 * * *$ & $0.158 * * *$ \\
\hline & $(0.031)$ & $(0.034)$ & $(0.034)$ \\
\hline \multirow[t]{2}{*}{ Year 2009} & $0.436 * * *$ & 0.091 & 0.100 \\
\hline & $(0.081)$ & $(0.084)$ & $(0.083)$ \\
\hline \multirow[t]{2}{*}{ Year 2010} & $0.189 * *$ & $0.201^{* * *}$ & $0.196 * * *$ \\
\hline & $(0.065)$ & $(0.054)$ & $(0.053)$ \\
\hline \multirow[t]{2}{*}{ Year 2011} & $0.382 * * *$ & $-0.419 * * *$ & $-0.384 * *$ \\
\hline & $(0.106)$ & $(0.120)$ & $(0.120)$ \\
\hline \multirow[t]{2}{*}{ Year 2013} & $-0.445^{* * *}$ & -0.054 & -0.030 \\
\hline & $(0.107)$ & $(0.076)$ & $(0.076)$ \\
\hline \multirow[t]{2}{*}{ Year 2014} & $-0.189+$ & 0.068 & 0.084 \\
\hline & $(0.107)$ & $(0.078)$ & $(0.077)$ \\
\hline Year 2015 & $1.047^{* * *}$ & -0.149 & -0.105 \\
\hline & $(0.169)$ & $(0.184)$ & $(0.184)$ \\
\hline Constant & $3.281 * *$ & 0.442 & 0.365 \\
\hline & $(1.193)$ & $(0.459)$ & $(0.451)$ \\
\hline Random-effects Parameters & & & \\
\hline Country-level variance & 42.63 & 4.614 & 4.43 \\
\hline & $(12.739)$ & $(2.158)$ & $(1.963)$ \\
\hline Firm-level residual & 0.474 & 0.47 & 0.469 \\
\hline & $(0.005)$ & $(0.005)$ & $(0.005)$ \\
\hline Likelihood-ratio test & & & \\
\hline Degree of freedom & 16 & 19 & 21 \\
\hline LR chi ${ }^{2}$ & & $237.5^{* * *}$ & $28.21 * * *$ \\
\hline Observations & 17,757 & 17,757 & 17,757 \\
\hline Number of countries & 35 & 35 & 35 \\
\hline
\end{tabular}

Standard errors in parentheses; continuous variables all standardised; *** $p<0.001, * * p<0.01, * p<0.05,+p<0.1$. 
Table 1 Descriptive Statistics and Correlation of Variables

\begin{tabular}{|c|c|c|c|c|c|c|c|c|c|c|c|c|}
\hline & 1 & 2 & 3 & 4 & 5 & 6 & 7 & 8 & 9 & 10 & 11 & 12 \\
\hline Mean & 23553.69 & 2.11 & 6.24 & -0.14 & 1.48 & 15.54 & 0.10 & 13.49 & 1.57 & 3725.52 & 55.40 & 2009.70 \\
\hline Std. Dev. & 2600197 & 6.55 & 0.69 & 14.38 & 0.68 & 13.32 & 0.30 & 9.48 & 0.59 & 3185.55 & 56.70 & 3.22 \\
\hline Min & 0 & 0 & 4.79 & -25.55 & 1 & 1 & 0 & 0 & 1 & 559.39 & 1.25 & 2006 \\
\hline Max & 345000000 & 100 & 7.85 & 95.23 & 3 & 167 & 1 & 50 & 3 & 15306.39 & 176.00 & 2015 \\
\hline 1 Sales (million) & 1 & & & & & & & & & & & \\
\hline 2 Institutional Effectiveness & 0.13 & 1 & & & & & & & & & & \\
\hline 3 Top Management Efforts (\%) & 0.07 & $0.02^{d}$ & 1 & & & & & & & & & \\
\hline 4 Informal Payments (\%) & $0.01^{a}$ & $-0.02^{d}$ & 0.12 & 1 & & & & & & & & \\
\hline 5 Size & 0.39 & $0.02^{d}$ & 0.07 & -0.04 & 1 & & & & & & & \\
\hline 6 Age & 0.17 & $0.02^{c}$ & 0.04 & -0.03 & 0.33 & 1 & & & & & & \\
\hline 7 Ownership (foreign =1) & 0.21 & 0.03 & $0.02^{d}$ & $-0.02^{c}$ & 0.19 & 0.04 & 1 & & & & & \\
\hline 8 Management Experience & 0.11 & $-0.01^{a}$ & 0.04 & -0.04 & 0.20 & 0.53 & 0.05 & 1 & & & & \\
\hline 9 Sector & -0.04 & -0.07 & $-0.003^{a}$ & $0.004^{\mathrm{a}}$ & -0.15 & -0.13 & $-0.001^{a}$ & -0.08 & 1 & & & \\
\hline 10 GDP per cap_PPP (USD) & -0.20 & 0.47 & $0.001^{\mathrm{a}}$ & -0.03 & $-0.001^{a}$ & $-0.01^{b}$ & -0.03 & -0.04 & -0.07 & 1 & & \\
\hline 11 Population (million) & -0.15 & -0.06 & $0.01^{b}$ & 0.04 & $0.01^{\mathrm{a}}$ & $0.02^{d}$ & -0.17 & -0.06 & -0.12 & $-0.004^{a}$ & 1 & \\
\hline 12 Year & -0.12 & -0.05 & 0.09 & -0.04 & 0.07 & 0.16 & -0.04 & 0.14 & $0.002^{a}$ & $-0.01^{b}$ & 0.18 & 1 \\
\hline
\end{tabular}

Note: ${ }^{a}$ indicates $p>0.1,{ }^{b}$ indicates $p<0.1,{ }^{c}$ indicates $p<0.05,{ }^{d}$ indicates $p<0.01$, all the rest $p<0.001 ; n=17,757$. 
i On the difference between gifts and bribes, see Rose-Ackerman (1998). For a review of the literature on gift exchange see Dolfsma et al. (2008). 